\title{
Enhanced gene replacement in mycobacteria
}

\author{
Jason Hinds, ${ }^{1}$ Eshwar Mahenthiralingam, ${ }^{2}$ Karen E. Kempsell, ${ }^{3}$ \\ Ken Duncan, ${ }^{3}$ Richard W. Stokes, ${ }^{2}$ Tanya Parish ${ }^{1}$ and Neil G. Stoker ${ }^{1}$
}

Author for correspondence: Neil G. Stoker. Tel: +44171927 2425. Fax: +441716374314. e-mail: n.stoker@lshtm.ac.uk

1 Pathogen Molecular Biology and Biochemistry Unit, Department of Infectious and Tropical Diseases, London School of Hygiene \& Tropical Medicine, Keppel Street London WC1E 7HT, UK

2 Department of Pediatrics, University of British Columbia and B. C. Children's Hospital, British Columbia, Canada

${ }^{3}$ Glaxo Wellcome Research and Development, Stevenage, Herts, UK

\begin{abstract}
Allelic replacement will be a vital tool for understanding gene function in mycobacteria. Disruption of the chromosomal hisD gene of Mycobacterium smegmatis by standard gene replacement methods was surprisingly difficult, with most products being caused by illegitimate recombination (IR) events. A recombination assay was therefore developed and used to optimize conditions for homologous recombination (HR) in M. smegmatis. Treatment of competent cells with UV, hydrogen peroxide or mitomycin C did not improve the frequency of HR; however, treatment of the DNA with alkali or UV enhanced recombination frequency, while boiling did not. Applying these observations to allele replacement, UV and alkali treatment of transforming DNA increased HR events with pyrF and hisD, while the level of IR was unchanged. The introduction of ss phagemid DNA improved the level of HR and abolished IR. In Mycobacterium intracellulare the use of alkali-denatured DNA increased the numbers of recombinants obtained with an inactivated 19Ag gene, while in Mycobacterium tuberculosis, inactivation of a putative haemolysin gene, t/yA, was achieved using both UV-irradiated DNA and ss phagemid DNA.

Significantly, IR, which has been reported to be a problem in this species, was not observed. Thus, four genes in three species were successfully knocked-out using non-replicating DNA pretreated with alkali, UV or in an ss form. The use of these methods to enhance HR will greatly facilitate experiments to inactivate other genes in these important species.
\end{abstract}

Keywords: alkali-treated DNA, UV-irradiated DNA, haemolysin, homologous recombination, illegitimate recombination

\section{INTRODUCTION}

Mycobacterial disease is a major public health problem throughout the world (Raviglione et al., 1995). Development of new rational methods to control these diseases will depend on a greater understanding of the biology of the pathogens. An essential tool for understanding the biology of these organisms is the ability to inactivate genes at will, particularly as a large proportion of the genes have no known function (Cole $e t$ al., 1998).

Targeted gene replacement is routine in many bacteria, but has proved to be difficult in mycobacteria (McFadden, 1996). Work by Husson et al. (1990) showed that $p y r F$ mutants could be readily obtained by trans-

Abbreviations: HR, homologous recombination; IR, illegitimate recombination; SCO, single cross-over; DCO, double cross-over. forming Mycobacterium smegmatis with a non-replicating plasmid carrying $p y r F$ disrupted by a kanamycin resistance gene (kan). Kalpana et al. (1991) also successfully inactivated $M$. smegmatis genes using a gene library in an Escherichia coli plasmid vector, which was mutagenized with $\operatorname{Tn} 5$ and then transformed into the mycobacterium. However, when they transformed Mycobacterium tuberculosis with linear DNA, all the antibiotic-resistant transformants had arisen through illegitimate recombination (IR), with the fragment integrating at different sites in the chromosome in an apparently random manner. IR is rare in prokaryotes, but common in eukaryotic cells and this suggested that slow-growing mycobacteria such as M. tuberculosis might be unusual in having a high level of IR, perhaps accompanied by a depressed level of homologous recombination (HR). This idea was strengthened by the discovery of inteins in the recA genes of $M$. tuberculosis and Mycobacterium leprae (Davis et al., 1994). This 
again suggested that RecA activity and hence the level of HR might be suppressed, with the high level of IR being explained by the persistence of chromosomal breaks (McFadden, 1996), although this now seems unlikely (Papavinasasundaram et al., 1998). The first evidence that gene replacement was possible in slow-growing mycobacteria was in Mycobacterium intracellulare using a two-step selection procedure (Marklund et al., 1995) and in Mycobacterium bovis BCG using either a replicating vector (Norman et al., 1995) or a linearizedsuicide vector (Aldovini et al., 1993).

This paper describes experiments to inactivate $M$. smegmatis genes and the use of a recombination assay to identify conditions in which HR is enhanced. These results were then applied to gene replacement experiments in $M$. smegmatis, $M$. intracellulare and $M$. tuberculosis.

\section{METHODS}

Bacterial strains and plasmids. Bacterial strains and plasmids used in the work described here are listed in Table 1. Escherichia coli strains were cultured as described by Sambrook et al. (1989). Mycobacteria were grown in Lemco broth (Lab Lemco powder, $5 \mathrm{~g} \mathrm{l}^{-1}$; Bacto peptone, $5 \mathrm{~g} \mathrm{l}^{-1}$; $\mathrm{NaCl}, 5 \mathrm{~g} \mathrm{l}^{-1} ; 0.05 \%$ Tween 80 ; used for M. smegmatis only) or on Middlebrook $7 \mathrm{H} 10$ agar or $7 \mathrm{H} 9$ broth (Difco) containing oleic acid dextrose complex (OADC) without added catalase. Gentamicin was added at $5 \mu \mathrm{g} \mathrm{ml}^{-1}$, hygromycin $\mathrm{B}$ at $100 \mu \mathrm{g} \mathrm{m}^{-1}$ and kanamycin at $15 \mu \mathrm{g} \mathrm{ml}^{-1}$ where appropriate.

Electroporation of mycobacteria. M. smegmatis was electroporated as described by Snapper et al. (1990) and Parish \& Stoker (1995). M. intracellulare was prepared for electroporation as described previously (Marklund et al., 1995) except that all washes were carried out at room temperature. M. tuberculosis was electroporated as described previously (Parish \& Stoker, 1995) except that all washes were carried out at room temperature (Wards \& Collins, 1996).
DNA purification and manipulations. Purification of plasmid DNA from $E$. coli and all DNA manipulations were carried out using standard procedures (Sambrook et al., 1989). ssDNA was prepared using the protocols provided for the pGEM system (Promega) in E. coli JM109. Plasmid DNA was prepared from mycobacteria using mechanical lysis of the bacteria with glass beads followed by DNA purification using the Wizard Miniprep System (Promega). Genomic DNA was isolated from $M$. smegmatis and $M$. tuberculosis by the method of Santos et al. (1992). Chromosomal DNA was extracted from $M$. intracellulare for PCR analysis using a miniprep method (Lee et al., 1991).

PCR amplification. Primers HISP1 (5' TATAGATCTGGACTGATCAGGGACAATG $3^{\prime}$ ), complementary to nt 280-307, and HISP6 (5' AGACATTACCGCTCGAA 3'), complementary to nt $1647-1631$ of the $M$. smegmatis hisD sequence (accession no. X65542; Hinshelwood \& Stoker, 1992), were used to amplify a $1367 \mathrm{bp}$ fragment containing the coding sequence of the hisD gene. Amplification was carried out in $50 \mu$ containing 50 pmol each primer, $0.2 \mathrm{mM}$ each dNTP, 2.5 units Biotaq polymerase (Bioline), $5 \mu \mathrm{l} 10 \times$ buffer (Bioline) containing $15 \mathrm{mM} \mathrm{Mg}^{2+}$ and $1 \mathrm{ng}$ cosmid pCMH13 DNA (Hinshelwood \& Stoker, 1992). PCR was carried out using 30 cycles of $95^{\circ} \mathrm{C}$ for $1 \mathrm{~min}, 55^{\circ} \mathrm{C}$ for $1 \mathrm{~min}$ and $70^{\circ} \mathrm{C}$ for $1 \mathrm{~min}$. The resulting product was cloned into the TA cloning vector pCRII to create $\mathrm{pSYCH} 03$. The amplification pattern obtained with PCR primers BIM-9 (5' AACAAGTCGGGAACGAGCG $\left.3^{\prime}\right)$ and BIM-10 (5' TTGATTTCGAACGGTTTG 3'), which flanked the $A f l$ III site of $19 A g$ gene disruption (see Fig. 1d), was used as a screen for the type of recombination event undergone with plasmid $\mathrm{p} 19 \mathrm{~K} 5$ (Mahenthiralingam et al., 1998).

Preparation of plasmid DNA for electroporation. Plasmid DNA $(1-2 \mu \mathrm{g})$ was denatured in $20 \mu \mathrm{l} 0.2 \mathrm{M} \mathrm{NaOH}$ containing $0.2 \mathrm{mM}$ EDTA for $30 \mathrm{~min}$ at $37^{\circ} \mathrm{C}$. Two microlitres of $3 \mathrm{M}$ sodium acetate, $\mathrm{pH} 4.8$, and $80 \mu$ l ethanol were added and the DNA precipitated at $-70^{\circ} \mathrm{C}$. The DNA pellet was washed twice with $70 \%$ ethanol, dried under vacuum and dissolved in $10 \mu \mathrm{l}$ sterile deionized water. ssDNA was kept on ice $(1-2 \mathrm{~h})$ or frozen for storage at $-20^{\circ} \mathrm{C}$, prior to electroporation.

Table 1. Strains and plasmids

\begin{tabular}{|c|c|c|}
\hline Strain or plasmid & Relevant features & Source \\
\hline E. coli $\mathrm{DH} 5 \alpha$ & $\operatorname{rec} A$ & Life Technologies \\
\hline E. coli JM109 & $\mathrm{F}^{+}$(used for ssDNA preparation) & Promega \\
\hline M. smegmatis $\mathrm{mc}^{2} 155$ & & Snapper et al. (1990) \\
\hline M. tuberculosis $\mathrm{H} 37 \mathrm{Rv}$ & & Laboratory stock \\
\hline M. intracellulare 1403 (ATCC 35716) & & Trudeau Collection \\
\hline pCRII & PCR cloning vector & Invitrogen \\
\hline pGEM3Zf $(+)$ & Phagemid vector & Promega \\
\hline pSYCH03 & $1.4 \mathrm{~kb}$ his $D$ PCR product in pCRII & This work \\
\hline pSYCH09 & hisD: hyg suicide vector & This work \\
\hline pAGAN40 & hyg E. coli-mycobacteria shuttle vector & This work \\
\hline pRAM4 & Recombination assay vector & This work \\
\hline pCIG19 & $\begin{array}{l}2.4 \mathrm{~kb} M . \text { tuberculosis DNA containing tlyA in } \\
\text { pUC18 }\end{array}$ & Wren et al. (1998) \\
\hline pHLY3 & tlyA:: hyg suicide vector & This work \\
\hline p19K5 & $19 \mathrm{Ag}:: \mathrm{Gm}$ suicide vector & Mahenthiralingam et al. (1998) \\
\hline pY6002 & pyrF::kan suicide vector & Husson et al. (1990) \\
\hline
\end{tabular}


For UV treatment of DNA, plasmid DNA was subjected to 25, 100 or $300 \mathrm{~mJ} \mathrm{UV} \mathrm{irradiation} \mathrm{cm}^{-2}$ in a UV Stratalinker 1800 (Stratagene). Boiling treatment involved incubating plasmid DNA in a boiling water bath for $15 \mathrm{~min}$ followed by $10 \mathrm{~min}$ cooling on ice. ss phagemid DNA was generated from E. coli JM109 using helper phage R408 following protocols provided with the pGEM Single Strand System (Promega). Purification of ss phagemid DNA was performed using the Wizard M13 DNA Purification System (Promega).

Recombination assay. pRAM4 DNA was prepared from a recA-deficient strain of E. coli, such as DH $5 \alpha$, and $1 \mu \mathrm{g}$ was electroporated into $M$. smegmatis. After a $2 \mathrm{~h}$ recovery incubation, the bacteria were plated onto selective plates containing either hygromycin, kanamycin or hygromycin plus kanamycin. For treatment with DNA damaging agents, the cells were treated immediately after transformation with either UV irradiation at $45,100,200$ and $400 \mathrm{~m} \mathrm{~J} \mathrm{~cm}^{-2}$, hydrogen peroxide at 44,88 and $132 \mathrm{mM}$ or mitomycin $\mathrm{C}$ at $0.005,0.05$ and $0.5 \mu \mathrm{g} \mathrm{ml}^{-1}$. Treatment with hydrogen peroxide and mitomycin $\mathrm{C}$ was for the $2 \mathrm{~h}$ recovery period, following which the cells were washed prior to plating.

\section{RESULTS}

\section{Gene replacement in $M$. smegmatis}

Other groups have readily obtained HR in M. smegmatis and we repeated experiments using the suicide vector pY6002 containing the $M$. smegmatis pyrF gene disrupted by insertion of a kan gene (Husson et al., 1990). It was introduced into $M$. smegmatis as either circular DNA or as a linear fragment (an EcoRI-XbaI fragment); colonies were obtained with all substrates and analysed. For pyrF, 12/194 (6\%) of the transformants from circular DNA were uracil auxotrophs, compared to $3 / 72(4 \%)$ with linear DNA. One auxotroph and five prototrophs were analysed by Southern blotting (not shown). The uracil auxotrophs showed the expected pattern for a double cross-over (DCO); of the prototrophs, 4/5 had undergone a single cross-over (SCO) HR event, while $1 / 5$ had arisen through IR. Thus, using pyrF, HR was readily achieved, with the majority of events being SCOs.

Having obtained HR with pyrF, we carried out similar experiments with the $M$. smegmatis his $D$ gene encoding histidinol dehydrogenase (Hinshelwood \& Stoker, 1992), which catalyses the final two steps in histidine biosynthesis (Alifano et al., 1996). pSYCH09, a nonreplicating (suicide) vector containing the hisD gene disrupted by insertion of a hygromycin resistance gene (byg) (Fig. 1c) was electroporated into M. smegmatis and low numbers of hygromycin-resistant $\left(\mathrm{Hyg}^{\mathrm{R}}\right)$ transformants were obtained (0-25 $\mu \mathrm{g}$ DNA). One hundred and forty six transformants were obtained from several electroporations; however, none was auxotrophic and all of those examined by Southern blotting were found to be IR events (not shown; these transformants are currently being characterized). We concluded that the level of HR with the hisD construct was low, such that it was below the background level of IR, because of either the gene itself or some technical factor such as the length of flanking DNA. Therefore, we carried out experiments to improve the system, both for 'difficult' genes in $M$. smegmatis and for $M$. tuberculosis, where gene replacement has proved more troublesome.

\section{Recombination assays in $M$. smegmatis}

To identify experimental conditions for application in gene replacement experiments that favoured HR, a plasmid-based recombination assay was developed which would generate quantitative results. The recombination assay vector, pRAM4, was constructed based upon restoration of a functional hyg gene by an HR event between two overlapping fragments of the $h y g$ gene flanking a functional kan gene in a shuttle plasmid (Fig. 1a, b). Intraplasmid HR between the duplicated DNA would restore a complete and functional hyg gene, deleting the kan cassette in the process. Neither of the fragments of byg used could confer resistance to hygromycin on their own.

$\mathrm{Kan}^{\mathrm{R}}$ pRAM4 transformants were picked and grown in Lemco broth containing kanamycin and plated onto Lemco plates containing kanamycin, hygromycin or kanamycin plus hygromycin. Transformants were obtained on all the selective media used, indicating that the native $\left(\mathrm{Kan}^{\mathrm{R}}\right)$ pRAM4 vector was able to rearrange by HR to produce $\mathrm{Hyg}^{\mathrm{R}}$ colonies. Plasmid DNA was isolated from transformants and digested with restriction enzymes. The plasmids from $\mathrm{Hyg}^{\mathrm{R}}$ and $\mathrm{Kan}^{\mathrm{R}}$ colonies had the expected structures, while plasmid DNA isolated from the double antibiotic selection indicated that these were colonies in which both native and recombined forms of pRAM4 were present, which we would expect to segregate in the absence of a double antibiotic selection (not shown). The mean frequency of recombination using untreated plasmid was $4.6 \times 10^{-3}$ $\left\langle n=8 ; \sigma=4.7 \times 10^{-3}\right)$.

Attempts to improve the level of HR by modification to the standard transformation protocol did not produce any significant benefits. Modifications assessed included the use of freshly prepared rather than frozen competent $M$. smegmatis and cells prepared at different growth stages. Treatment of transformed M. smegmatis with DNA damaging agents was also evaluated using the recombination assays. UV irradiation of transformed M. smegmatis at energies of $45-400 \mathrm{~mJ} \mathrm{~cm}^{-2}$ produced no significant effect upon recombination frequencies or transformant numbers (not shown). Hydrogen peroxide treatment of transformed $M$. smegmatis at concentrations of 44-132 mM or mitomycin C treatment of $M$. smegmatis at concentrations of $0.005-0.5 \mu \mathrm{g} \mathrm{ml}^{-1}$ produced no beneficial effect upon the level of HR, but greatly reduced cell viability (not shown).

An alternative approach for trying to boost the level of HR was altering the state of the DNA used in transformations to provide a more recombinogenic substrate, or to induce the expression of proteins involved in DNA repair mechanisms. Pretreatment of DNA by alkali denaturation, boiling or UV irradiation prior to transformation was evaluated using recombination assays. 
(a)

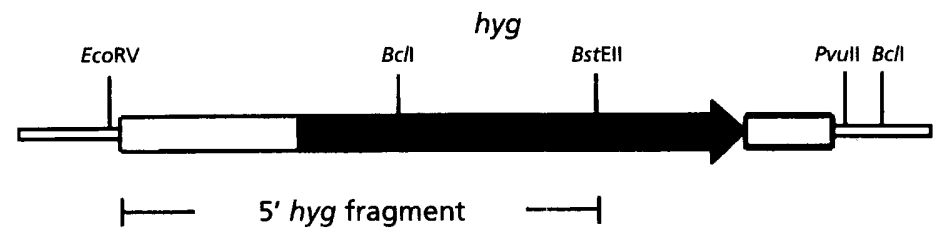

$10.5 \mathrm{~kb}-1$

$\longmapsto \quad 3^{\prime}$ hyg fragment $\quad \longrightarrow$
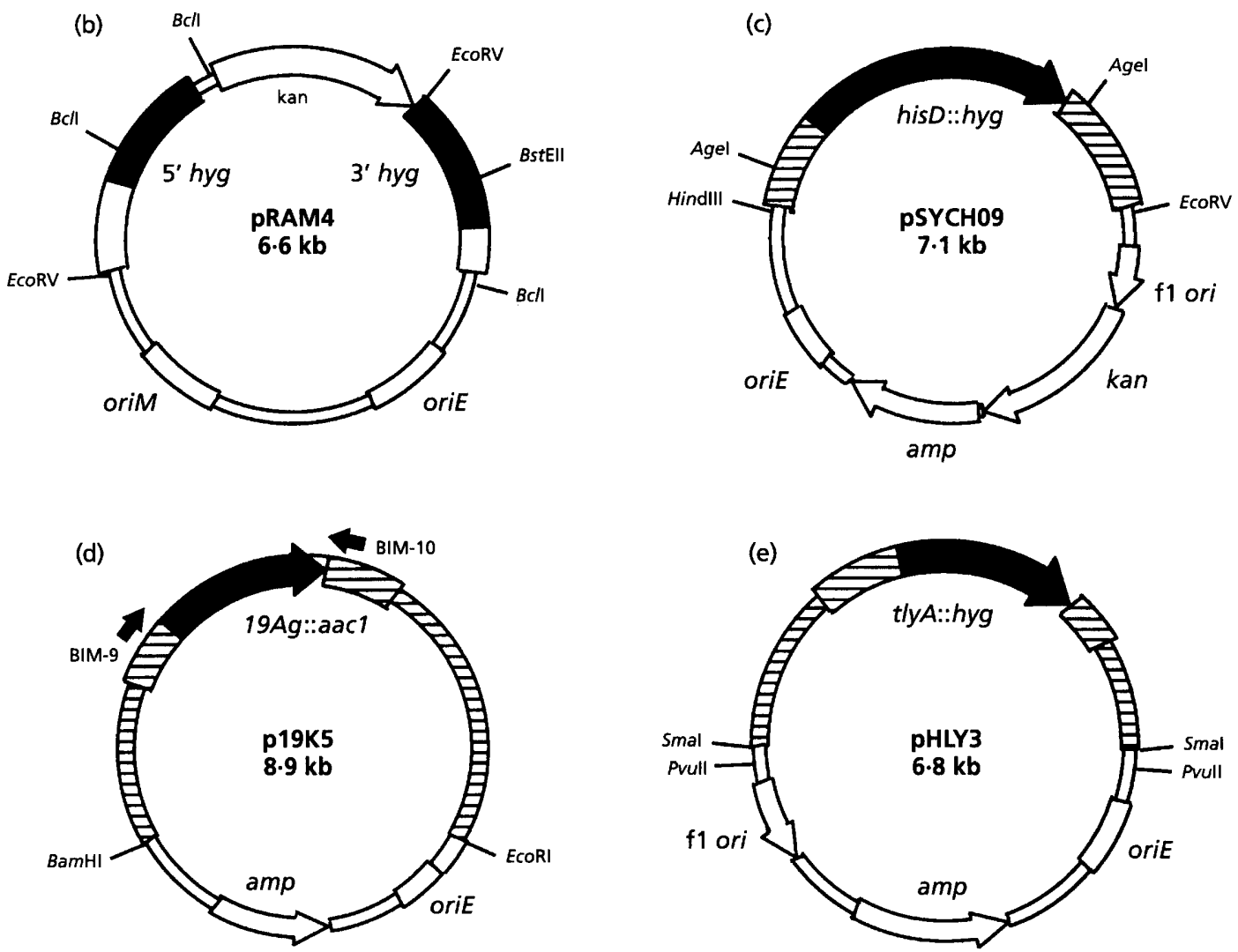

Fig. 1. Plasmid diagrams. (a) pAGAN40, of which the region containing the hyg cassette is shown here, was constructed by cloning a Bg/ll fragment containing a hyg cassette from plJ963 (Lydiate et al., 1989) into the BamHI site within the multiple cloning site of pMV206 (Stover et al., 1991). The wide bar shows the cassette used throughout this work; the black arrow indicates the coding sequence. Below, the regions used in constructing pRAM4 are indicated. (b) pRAM4. Recombination assay vector, containing $517 \mathrm{bp}$ duplication of the hyg gene surrounding the kan gene. The 5' EcoRVBstEll hyg region and the $3^{\prime} B C / 1-P v u l l$ region were cloned into pMV206. The $5^{\prime}$ and $3^{\prime}$ regions are indicated underneath the hyg cassette of pAGAN40 (see above). Shading as for (a). (c) pSYCH09 suicide vector. The hisD gene from $M$. smegmatis was amplified as a $1.4 \mathrm{~kb}$ fragment and cloned into pCRII (Invitrogen) to produce pSYCH03. The hyg gene from pAGAN40 (a) was excised as an EcoRV-Pvull fragment and inserted into the unique Nrul site in the middle of hisD. In this diagram, the black arrow indicates the entire hyg cassette, including non-coding regions, while the cross-hatched bars indicate the hisD coding sequence. The mycobacterial DNA regions flanking the hyg gene were 0.6 and $0.8 \mathrm{~kb}$ in length. (d) p19K5 suicide vector (Mahenthiralingam et al., 1998). The $M$. intracellulare 19Ag ORF, aacC1 (gentamicin resistance, $\mathrm{Gm}^{\mathrm{R}}$ ) gene insertion and binding sites for PCR primers BIM-9 and BIM-10 are shown. The black arrow indicates the entire aacC1 cassette, including non-coding regions, while the cross-hatched regions indicate the $M$. intracellulare DNA, the wide bar being the $19 \mathrm{kDa}$ coding sequence. The mycobacterial DNA regions flanking the aacC1 gene were 1.9 and $4.3 \mathrm{~kb}$ in length. (e) pHLY3 suicide vector. A $0.3 \mathrm{~kb}$ EcoRV-Spel t/yA fragment was replaced with the hyg gene (Xbal-Smal) in the same transcriptional orientation as in PCIG19 (Wren et al., 1998) followed by excision of the complete $3.6 \mathrm{~kb}$ Smal fragment and insertion into the phagemid vector pGEM3Zf $(+)$. The black arrow indicates the entire hyg cassette, including non-coding regions, while the cross-hatched regions indicate the $M$. tuberculosis DNA, the wide bar being the tlyA coding sequence. The mycobacterial DNA regions flanking the hyg gene were each $1 \cdot 25 \mathrm{~kb}$ in length. amp, ampicillin resistance gene; kan, kanamycin resistance gene; oriE, $E$. coli origin of replication; hyg, hygromycin resistance gene; oriM, mycobacterial origin of replication; $f 1$ ori, origin for generation of ss phagemid DNA. 


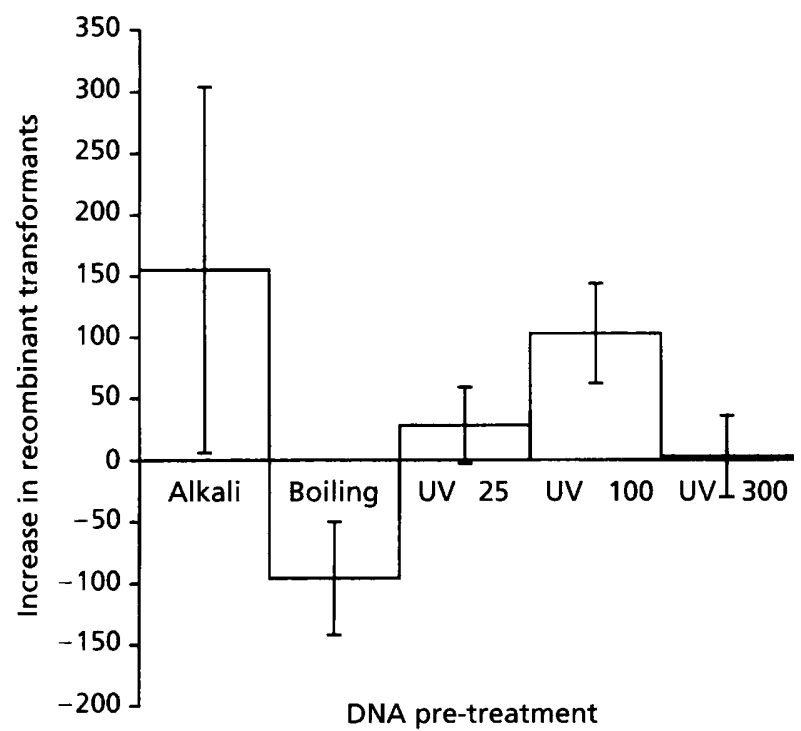

Fig. 2. Effect of treatment of plasmid DNA on recombination frequencies. Recombination assays were performed as described in Methods and the total number of $\mathrm{Kan}^{\mathrm{R}}$ and $\mathrm{Hyg}^{\mathrm{R}}$ colonies were counted. Results are expressed as the increase in numbers of recombinants ( $\mathrm{Hyg}^{\mathrm{R}}$ transformants) over the control using untreated DNA. The means $\pm S D$ of four independent experiments are shown. DNA was treated as described in the Methods.

Alkali treatment of DNA showed a marked increase in the number of recombinants (Fig. 2). While this work was in progress, Oh \& Chater (1997) reported that alkali treatment of DNA improved HR in Streptomyces coelicolor A3(2), consistent with our results. Boiling DNA prior to transformation might have been expected to enhance recombination in the same way as alkali did, as it would also denature the DNA. However, it reduced the number of recombinants (Fig. 2), although this was largely due to lower transformation efficiency, perhaps because the incubation was too long and caused irreparable damage to the DNA.

UV irradiation of DNA at $25 \mathrm{~mJ} \mathrm{~cm}^{-2}$ prior to transformation slightly increased the number of recombinants and $100 \mathrm{~m} \mathrm{~J} \mathrm{~cm}^{-2}$ was even more effective (Fig. 2). At $300 \mathrm{~mJ} \mathrm{~cm}^{-2}$, however, there was no increase; as with boiling, this appeared to be due to excessive DNA damage, as the total number of transformants dropped sharply (not shown).

\section{Improvement of gene replacement frequency}

It was possible that factors causing an increase in intraplasmid recombination might not be effective in improving recombination between plasmid and chromosome, which is necessary for gene replacement. Therefore, the effect of using alkali-denatured or UVirradiated DNA on HR was assessed using the $M$. smegmatis pyrF gene replacement vector pY6002. Transformant numbers were increased using alkali- or UVtreated DNA (Table 2), with the alkali enhancement being statistically significant $(P<0 \cdot 01)$. Transformation numbers obtained with $1 \mu \mathrm{g}$ untreated $E$. coli vector DNA were reduced, but not significantly, using alkalidenatured DNA; thus IR still occurred, but the relative frequency of these events decreased as the number of HR events increased. To confirm what events had taken place, colonies were tested for auxotrophy (indicating DCO events). Four out of 81 colonies tested were uracil auxotrophs. DNA from one of the auxotrophs and 11 prototrophs were analysed on Southern blots. The auxotroph had the expected DNA profile, while 8/11 of the prototrophs were SCO events and the remaining three were illegitimate. Thus in this experiment, $4.9 \%$ of transformants were DCOs, $69 \cdot 2 \%$ were SCOs and $25 \cdot 9 \%$ were illegitimate.

The effect of using alkali-denatured or UV-irradiated DNA on M. smegmatis hisD gene replacement was then assessed using pSYCH09 (Table 2). The number of

Table 2. Colonies produced in $M$. smegmatis following electroporation with suicide plasmids

\begin{tabular}{|c|c|c|c|c|c|c|}
\hline \multirow[t]{2}{*}{ Vector } & \multirow[t]{2}{*}{ Treatment } & \multirow[t]{2}{*}{$n^{*}$} & \multicolumn{2}{|c|}{ Untreated DNA } & \multicolumn{2}{|c|}{ Treated DNA } \\
\hline & & & No. of colonies & SD & No. of colonies & SD \\
\hline \multirow[t]{3}{*}{ pSYCH09 (hisD) } & Alkali & 16 & $2 \cdot 6$ & $2 \cdot 3$ & $5 \cdot 2$ & $6 \cdot 1$ \\
\hline & UV & 4 & $2 \cdot 3$ & $2 \cdot 6$ & $6 \cdot 3$ & $2 \cdot 9$ \\
\hline & ssDNA & 9 & $5 \cdot 3$ & $8 \cdot 6$ & $1 \cdot 0$ & $1 \cdot 2$ \\
\hline \multirow[t]{2}{*}{ pY6002 (pyrF) } & Alkali & 11 & $48 \cdot 3$ & $39 \cdot 4$ & $384 \cdot 0+$ & $393 \cdot 0$ \\
\hline & UV & 4 & $18 \cdot 2 \pm 6 \cdot 8$ & $13 \cdot 6$ & $328 \cdot 0$ & $146 \cdot 0$ \\
\hline \multirow[t]{2}{*}{ E. coli vector } & Alkali & 9 & $2.7 \pm 0.7$ & $2 \cdot 0$ & $0 \cdot 8$ & $0 \cdot 8$ \\
\hline & ssDNA & 14 & $7 \cdot 2 \pm 3 \cdot 5$ & $12 \cdot 9$ & $0.0 \dagger$ & $0 \cdot 0$ \\
\hline
\end{tabular}

* Each pair within each treatment used a separate preparation of competent cells.

$+P<0.01$ according to Wilcoxon's signed rank sum test. 
(a)

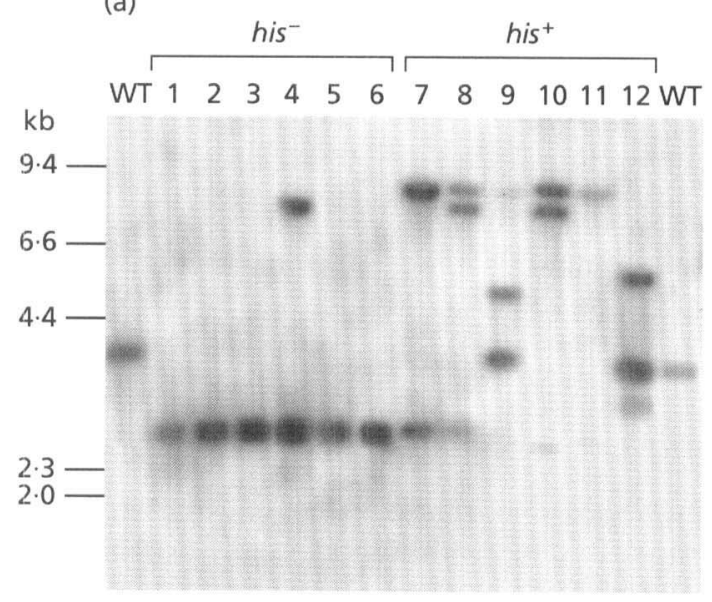

(b)

$$
\begin{aligned}
& \text { his }^{-} \quad \text { his }^{+} \\
& \begin{array}{lllllllllllll}
\text { WT } 1 & 2 & 3 & 4 & 5 & 6 & 7 & 8 & 9 & 10 & 11 & 12 & \text { WT }
\end{array}
\end{aligned}
$$

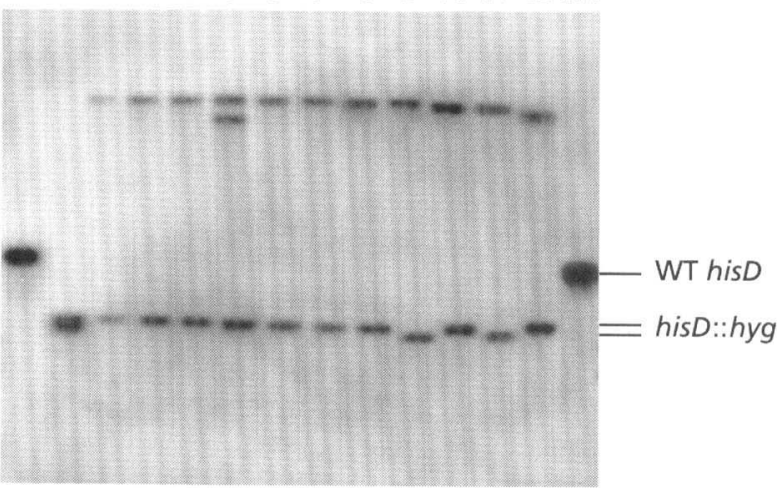

Fig. 3. Southern analysis of $M$. smegmatis hisD::hyg transformants. Genomic DNA was isolated from $M$. smegmatis transformants generated with (a) alkali-denatured DNA and (b) ss phagemid DNA. The figure shows blots of $1 \mu \mathrm{g}$ DNA digested with Smal and hybridized with labelled $1.4 \mathrm{~kb}$ hisD probe. WT, wild-type DNA.

colonies obtained using treated DNA was not significantly different compared to untreated DNA. However, the HR rate was much better, with $7 / 62(11 \cdot 3 \%)$ and $3 / 24(12 \cdot 5 \%)$ transformants being his auxotrophs after alkali and UV treatment, respectively, in great contrast to untreated pSYCH09 DNA, where no auxotrophs were seen in 146 transformants. Southern blotting of six auxotrophs showed that five had a straightforward DCO (Fig. 3a, lanes 1-3, 5-6); SmaI cuts the disrupted gene into two bands of 2.4 and $2.7 \mathrm{~kb}$, which are not clearly resolved in the figure. One of the auxotrophs (Fig. 3a, lane 4) contained an extra copy of hisD on a band of a size consistent with an SCO event in addition to the DCO (as if the entire $7 \cdot 1 \mathrm{~kb}$ pSYCH09 had integrated into the disrupted gene, either by plasmid dimer formation, or after the first chromosomal integration); this explanation was supported by the fact that a similar band was seen in other tracks (see below).

Prototrophic transformants were again found to be a mixture of events generated by SCO HR and IR events. SCO events lost the wild-type band, but gained either a 2.4 or $2.7 \mathrm{~kb}$ band (Fig. 3a, lanes $7-8,10-11$ ). Two of these had an extra $7 \cdot 1 \mathrm{~kb}$ band (lanes 8,10 ), indicating the presence of a second copy of the plasmid in the hisD locus. The IR events left the wild-type $3.6 \mathrm{~kb} \mathrm{SmaI}$ fragment intact and have an extra band of a different size (Fig. 3a, lanes 9, 12). Thus the use of denatured or irradiated DNA produced a marked improvement in the frequency of $\mathrm{HR}$ and achieved hisD gene inactivation.

Following the improvement achieved using denatured DNA, the effect of using ss phagemid DNA was assessed using pSYCH09 (Table 2). A striking observation was the total abolition of illegitimate events with vector DNA, which was statistically significant $(P<0.01)$. One out of 14 transformants tested was a histidine auxotroph and Southern blotting confirmed that this transformant was produced by a DCO HR event (Fig. 3b, lane 1). The prototrophic transformants analysed were all found to have arisen from SCO HR events, with patterns identical to those obtained previously (Fig. 3b, lanes 2-12). Thus ssDNA was not a suitable template for integration by IR, but was able to participate in HR efficiently in $M$. smegmatis - an ideal substrate for gene replacement experiments.

\section{Gene replacement in $\boldsymbol{M}$. intracellulare}

The effect of using denatured dsDNA as a mutagenesis template was examined in $M$. intracellulare using the gene encoding the $19 \mathrm{kDa}$ lipoprotein antigen (Booth et al., 1993; Prestidge et al., 1995) as a model target. Successful gene replacement of this gene using a suicide vector mutagenesis strategy had been carried out in $M$. intracellulare strain 1403, with native dsDNA as the mutagenesis template (Mahenthiralingam et al., 1998). The $19 \mathrm{kDa}$ suicide plasmid, p19K5 (Fig. 1d), was introduced into $M$. intracellulare by electroporation in both denatured and native form. DNA recombination among the transformants was assessed using a PCR screen with primers BIM-9 and BIM-10, the binding sites of which flanked the point of $19 \mathrm{Ag}$ gene disruption (see Fig. 1d). Two patterns of $19 \mathrm{Ag}$ gene amplification were seen among transformants, a single product corresponding to the mutant allele (indicating a DCO) or two bands corresponding to the wild-type and mutant alleles (indicating either SCO or IR events). The use of denatured dsDNA increased the number of transformants $(\mu \mathrm{g} \mathrm{DNA})^{-1}$ fourfold (from $10 \mu \mathrm{g}^{-1}$ for native DNA to $40 \mu \mathrm{g}^{-1}$ for denatured DNA). In addition, the number of clones which appeared to have undergone DCO HR with the suicide vector increased from 10 to $76 \%$ of the total examined when denatured DNA was used (10/51 for native DNA; 40/50 for denatured DNA). Allelic replacement of the $19 \mathrm{Ag}$ gene and abrogation of protein expression was demonstrated by 


\section{$23456 / 889101112$}

$k b$

$6 \cdot 6$

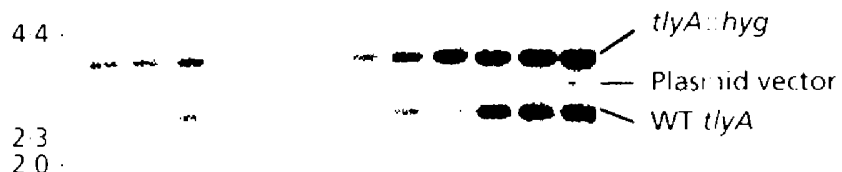

Fig. 4. Southern analysis of $M$. tuberculosis tlyA::hyg transformants. Genomic DNA was isolated from $12 \mathrm{M}$. tuberculosis transformants generated using ss phagemid DNA. One microgram was digested with Smal and hybridized to the tlyA::hyg probe (Fig. 1e). Lanes 1 and 6 show the expected pattern for a $\mathrm{DCO}$, all other lanes show a pattern indicative of an SCO. The bands corresponding to the wild-type allele (WT t/yA), disrupted allele (t/yA::hyg) and plasmid vector sequences are indicated. The vector bands are indicated. These are fainter than the other bands because they are present due to contaminating vector DNA in the probe.

Southern hybridization and immunoblot, respectively, for two putative DCO transformants (Mahenthiralingam et al., 1998).

\section{Gene replacement in $\boldsymbol{M}$. tuberculosis}

The methodology of using UV-irradiated dsDNA and ss phagemid DNA was also applied to gene replacement in $M$. tuberculosis using a putative hacmolysin-encoding gene $(t l y A)$ (Wren et al., 1998). Transformation with the suicide vector pHLY3 (Fig. 1e) generated 10 transformants using $5 \mu \mathrm{g}$ UV-irradiated plasmid dsDNA and 12 transformants using $2 \mu \mathrm{g} s \mathrm{~s}$ phagemid DNA, while no colonies were obtained using untreated DNA. Southern blotting of 20 transformants thus generated 8 from dsDNA, 12 from ss phagemid DNA! showed that all arose by HR events, with no IR being observed. The 12 transformants obtained using phagemid DNA are shown in Fig. 4; all transformants contain the $3.6 \mathrm{~kb}$ band containing the $t l y A:$ : $b y g$ construct, while two lack the $2.4 \mathrm{~kb}$ wild-type tly $A$ band. All the strains with putative SCO events contain the plasmid vector, while those with putative DCO events do not (Fig. 4, lanes 1 and 6). Analysis of DNA digested with PvulI (which cuts within the probe; not shown) confirmed that the other 18 transformants tested were all SCOs rather than IR events. Thus using phagemid DNA, 2/12 transformants $\left(16^{\prime \prime}, 1\right)$ had arisen from a DCO HR event, while the other 10 contained SCO events. Using UV-irradiated plasmid DNA, $1 / 8(12 \%)$ of the transformants was produced by DCO and $7 / 8$ by SCO HR events.

\section{DISCUSSION}

The inactivation or mutation of genes in a targeted fashion has been difficult in slow-growing mycobacteria. It is difficult to generalize from other work, because one feature of gene replacement is that different genes behave differently; while inactivation of one gene may be obtained readily, another may prove refractory. For example, one reason for the success using $p y r F$ compared to bis D may be the longer flanking DNA in the pyrl: construct $(2-3 \mathrm{~kb}$, compared to $0.6-0.8 \mathrm{~kb}$ with hisD). However, we have used other genes in $M$. smegmatis with several kb of flanking DNA and none has been as easy to inactivate as $p y r F$, suggesting other factors are also involved. Whatever the causes of these differences, the way forward secms to be to develop methods which optimize the possibilities of obtaining a mutant. This would include increasing the rate of $\mathrm{HR}$, reducing the background of spontaneous mutants or IR cvents, increasing the total numbers of colonies obtained and improving the selection and screening methods to reduce the number of colonie's that need analysing.

We have shown that HR in M. smegmatis using nonreplicating suicide plasmid vectors was enhanced by the use of $\operatorname{ss} \mathrm{DNA}$ (either generated by alkali denaturation of a dsDNA plasmid template or by production of ss phagemid DNA), as reported for S. coelicolor A3(2) (Oh \& Chater, 1997), or alternatively by the use of UVirradiated dsDNA. Using these techniques, gene replacement was improved with two genes in $M$. smegmatis and with genes in two slow-growing mycobacterial species, $M$. intracellulare and $M$. tuberculosis. The improvement in HR seen may be duc to stimulation of rec A or other DNA repair systems. The stimulation of HR by L'V may be caused by the production of a gapped duplex substrate following nucleotide excision repair (by LvrABC). This has been shown to be an effective recombination substrate due to the rapid formation of RecA filaments (Friedberg et al., 1995). Although both alkali and UV appear to work, caution may be necessary when using UV, as there is the potential for the induction of point mutations in the recombined D.VA.

IR was reported as being a serious problem in $M$. tuberculosis, but not in $M$. smegmatis (Kalpana et al., 1991). We have shown that there is also a background level of IR in the fast-growing species; although this is not a major obstacle when using genes where $H R$ is high, it can cause difficulties where HR is low. We obtained fewer background colonies using alkali, although this did not reach statistical significance. However, the use of ss phagemid DNA totally removed this problem - to date we have not sten IR in $M$. smegmatis using this technique. Furthermore, we obtained similar results in $M$. intracellulare and $M$. tuberculosis, strongly suggesting that IR need not be a problem in slow-growing mycohacteria, even if it is true that the rate of IR is higher than in fast-growing species.

Successful gene replacement has now been achieved in BCG using non-replicating circular (Norman et al., 1995) or linear (Reyrat et al., 1995; Azad et al., 1996, 1997) DNA and in M. tuberculosis using long linear DNA substrates (Balasubramanian et al., 1996) or a thermosensitive replicating plasmid (Pelicic et al., 1997). The need to develop the ability to inactivate genes at will 
is even greater, now that the genome sequence of $M$. tuberculosis has been completed (Cole et al., 1998). Our methodology is very simple and does not require complex vector construction, as with the long linear substrate approach. Also, the ability to use E. coli plasmids may well be more practical than use of a shuttle vector with a mycobacterial origin of replication, in that finding suitable restriction sites for disruption in a particular gene can be difficult even without the extra DNA present. Pelicic et al.(1997) used $s a c B$ as a negative selectable marker and it would be possible to use this in conjunction with the system described here to select against SCOs. Another alternative would be to use selection for streptomycin sensitivity using $r p s L^{+}$ (Sander et al., 1995), although this requires a streptomycin-resistant host.

\section{ACKNOWLEDGEMENTS}

We are grateful to Rick Young for providing plasmids and strains and to Britt-Inger Marklund for identifying and providing $\mathrm{M}$. intracellulare $19 \mathrm{Ag}$ gene-encoding cosmid DNA. We are also grateful to Michael Jones for statistical advice, Steve West, Valerie Mizrahi and Pelle Stolt for helpful discussions, Nicki Casali for the TB DNA preparations and Heidi Robinson for technical assistance. J. H. was funded by a Glaxo Wellcome studentship, T.P. was funded by Wellcome Trust grant $0366088 / Z / 92$ and Glaxo Wellcome; E.M. was funded by the Canadian Bacterial Disease Network and Glaxo Wellcome; R.W.S. is a BC Lung/MRC (Canada) Scholar.

\section{REFERENCES}

Aldovini, A., Husson, R. N. \& Young, R. A. (1993). The uraA locus and homologous recombination in Mycobacterium bovis BCG. $J$ Bacteriol 175, 7282-7289.

Alifano, P., Fani, R., Lio, P., Lazcano, A., Bazzicalupo, M., Carlomagno, M. S. \& Bruni, C. B. (1996). Histidine biosynthetic pathway and genes: structure, regulation and evolution. Microbiol Rev 60, 44-69.

Azad, A. K., Sirakova, T. D., Rogers, L. M. \& Kolattukudy, P. E. (1996). Targeted replacement of the mycocerosic acid synthase gene in Mycobacterium bovis BCG produces a mutant that lacks mycosides. Proc Natl Acad Sci USA 93, 4787-4792.

Azad, A. K., Sirakova, T. D., Fernandes, N. D. \& Kolattukudy, P. E. (1997). Gene knockout reveals a novel gene cluster for the synthesis of a class of cell wall lipids unique to pathogenic mycobacteria. J Biol Chem 272, 16741-16745.

Balasubramanian, V., Pavelka, M. S., Jr, Bardarov, S. S., Martin, J., Weisbrod, T. R., McAdam, R. A., Bloom, B. R. \& Jacobs, W. R., Jr (1996). Allelic exchange in Mycobacterium tuberculosis with long linear recombination substrates. J Bacteriol 178, 273-279.

Booth, R. J., Williams, D. L., Moudgil, K. D., Noonan, L. C., Grandison, P. M., McKee, J. J., Prestidge, R. L. \& Watson, J. D. (1993). Homologs of Mycobacterium leprae 18-kilodalton and Mycobacterium tuberculosis 19-kilodalton antigens in other mycobacteria. Infect Immun 61, 1509-1515.

Cole, S. T., Brosch, R., Parkhill, J. \& 39 other authors (1998). Deciphering the biology of Mycobacterium tuberculosis from the complete genome sequence. Nature 393, 537-544.

Davis, E. O., Thangaraj, H. S., Brooks, P. C. \& Colston, M. J. (1994). Evidence of selection for protein introns in the RecAs of pathogenic mycobacteria. EMBO J 13, 699-703.
Friedberg, E. C., Walker, G. C. \& Siede, W. (1995). DNA Repair and Mutagenesis. Washington, DC: American Society for Microbiology.

Hinshelwood, S. \& Stoker, N. G. (1992). Cloning of mycobacterial histidine synthesis genes by complementation of a Mycobacterium smegmatis auxotroph. Mol Microbiol 6, 2887-2895.

Husson, R. N., James, B. E. \& Young, R. A. (1990). Gene replacement and expression of foreign DNA in mycobacteria. J Bacteriol 172, 519-524.

Kalpana, G. V., Bloom, B. R. \& Jacobs, W. R. (1991). Insertional mutagenesis and illegitimate recombination in mycobacteria. Proc Natl Acad Sci USA 88, 5433-5437.

Lee, M. H., Pascopella, L., Jacobs, W. R. \& Hatfull, G. F. (1991). Site-specific integration of mycobacteriophage-L5 - integrationproficient vectors for Mycobacterium smegmatis, Mycobacterium tuberculosis and Bacille Calmette-Guerin. Proc Natl Acad Sci USA 88, 3111-3115.

Lydiate, D. J., Ashby, A. M., Henderson, D. J., Kieser, H. M. \& Hopwood, D. A. (1989). Physical and genetic characterization of chromosomal copies of the Streptomyces coelicolor mini-circle. J Gen Microbiol 135, 941-955.

McFadden, J. (1996). Recombination in mycobacteria. Mol Microbiol 21, 205-211.

Mahenthiralingam, E., Marklund, B.-I., Brooks, L. A. \& Stokes, R. W. (1998). Site-directed mutagenesis of the 19-kilodalton lipoprotein antigen reveals no essential role for the protein in the growth and virulence of Mycobacterium intracellulare. Infect Immun 66, 3626-3634.

Marklund, B. I., Speert, D. P. \& Stokes, R. W. (1995). Gene replacement through homologous recombination in $\mathrm{Myco-}$ bacterium intracellulare. J Bacteriol 177, 6100-6105.

Norman, E., Dellagostin, O. A., McFadden, J. \& Dale, J. W. (1995). Gene replacement by homologous recombination in $\mathrm{Myco}$ bacterium bovis BCG. Mol Microbiol 16, 755-760.

Oh, S. H. \& Chater, K. F. (1997). Denaturation of circular or linear DNA facilitates targeted integrative transformation of Streptomyces coelicolor A3(2): Possible relevance to other organisms. J Bacteriol 179, 122-127.

Papavinasasundaram, K. G., Colston, M. J. \& Davis, E. O. (1998). Construction and complementation of a recA deletion mutant of Mycobacterium smegmatis reveals that the intein in $M y c o-$ bacterium tuberculosis recA does not affect RecA function. Mol Microbiol 30, 525-534.

Parish, T. \& Stoker, N. G. (1995). Electroporation of mycobacteria. In Electroporation Protocols for Microorganisms, pp. 237-252. Edited by J. A. Nickoloff. Totowa, NJ: Humana Press.

Pelicic, V., Jackson, M., Reyrat, J. M., Jacobs, W. R., Gicquel, B. \& Guilhot, C. (1997). Efficient allelic exchange and transposon mutagenesis in Mycobacterium tuberculosis. Proc Natl Acad Sci USA 94, 10955-10960.

Prestidge, R. L., Grandison, P. M., Chuk, D. W. W., Booth, R. J. \& Watson, J. D. (1995). Production of the $19-\mathrm{kDa}$ antigen of Mycobacterium tuberculosis in Escherichia coli and its purification. Gene 164, 129-132.

Raviglione, M. C., Snider, D. E., Jr \& Kochi, A. (1995). Global epidemiology of tuberculosis: Morbidity and mortality of a worldwide epidemic. JAMA 273, 220-226.

Reyrat, J. M., Berthet, F. X. \& Gicquel, B. (1995). The urease locus of Mycobacterium tuberculosis and its utilization for the demonstration of allelic exchange in Mycobacterium bovis bacillus Calmette-Guerin. Proc Natl Acad Sci USA 92, 8768-8772.

Sambrook, J., Fritsch, E. F. \& Maniatis, T. (1989). Molecular 
Cloning: a Laboratory Manual, 2nd edn. Cold Spring Harbor, NY: Cold Spring Harbor Laboratory.

Sander, P., Meier, A. \& Bottger, E. C. (1995). RpsL $L^{+}$: A dominant selectable marker for gene replacement in mycobacteria. Mol Microbiol 16, 991-1000.

Santos, A. R., Demiranda, A. B., Lima, L. M., Suffys, P. N. \& Degrave, W. M. (1992). Method for high yield preparation in large and small scale of nucleic acids from mycobacteria. J Microbiol Methods 15, 83-94.

Snapper, S. B., Melton, R. E., Mustafa, S., Kieser, T. \& Jacobs, W. R. (1990). Isolation and characterization of efficient plasmid transformation mutants of Mycobacterium smegmatis. Mol Microbiol 4, 1911-1919.

Stover, C. K., Delacruz, V. F., Fuerst, T. R. \& 11 other authors
(1991). New use of BCG for recombinant vaccines. Nature 351, 456-460.

Wards, B. J. \& Collins, D. M. (1996). Electroporation at elevated temperatures substantially improves transformation efficiency of slow-growing mycobacteria. FEMS Microbiol Lett 145, 101-105.

Wren, B. W., Stabler, R. A., Das, S. S., Butcher, P. D., Mangan, J. A., Clarke, J. D., Casali, N., Parish, T. \& Stoker, N. G. (1998). Characterization of a hemolysin from Mycobacterium tuberculosis with homology to a virulence factor of Serpulina hyodysenteriae. Microbiology 144, 1205-1211.

Received 14 September 1998; revised 1 December 1998; accepted 4 December 1998. 